\title{
Modeling the Risks of Climate Change and Global Warming to Humans Settled in Low Elevation Coastal Zones in Louisiana, USA
}

\author{
Yaw A. Twumasi ${ }^{*}$, Edmund C. Merem² ${ }^{2}$ John B. Namwamba', Tomas Ayala-Silva ${ }^{3}$, \\ Ronald Okwemba ${ }^{1}$, Olipa S. Mwakimi ${ }^{4}$, Kamran Abdollahi' ${ }^{1}$, Onyumbe E. Ben Lukongo5, \\ Kellyn LaCour-Conant ${ }^{1}$, Joshua Tate ${ }^{1}$, Caroline 0. Akinrinwoye ${ }^{1}$ \\ ${ }^{1}$ Department of Urban Forestry and Natural Resources, Southern University and A\&M College, Baton Rouge, LA, USA \\ ${ }^{2}$ Department of Urban and Regional Planning, Jackson State University, Jackson, MS, USA \\ ${ }^{3}$ USDA-ARS Tropical Agriculture Research Station, Mayaguez, Puerto Rico \\ ${ }^{4}$ Institute of Resource Assessment, University of Dares Salam, Dares Salam, Tanzania \\ ${ }^{5}$ Department of Public Policy, Southern University and A\&M College, Nelson Mandela College of Government and Social \\ Sciences, Baton Rouge, LA, USA \\ Email: ^yaw.twumasi@subr.edu, ^yaw.twumasi@gmail.com
}

How to cite this paper: Twumasi, Y.A., Merem, E.C., Namwamba, J.B., Ayala-Silva, T., Okwemba, R., Mwakimi, O.S., Abdollahi, K., Lukongo, O.E.B., LaCour-Conant, K., Tate, J. and Akinrinwoye, C.O. (2020) Modeling the Risks of Climate Change and Global Warming to Humans Settled in Low Elevation Coastal Zones in Louisiana, USA. Atmospheric and Climate Sciences, 10, 298-318.

https://doi.org/10.4236/acs.2020.103017

Received: April 6, 2020

Accepted: May 24, 2020

Published: May 27, 2020

Copyright $\odot 2020$ by author(s) and Scientific Research Publishing Inc. This work is licensed under the Creative Commons Attribution International License (CC BY 4.0).

http://creativecommons.org/licenses/by/4.0/

(c) (i) Open Access

\begin{abstract}
This paper seeks to identify high risk areas that are prone to flooding, caused by sea level rise because of high impacts of global climate change resulting from global warming and human settlements in low-lying coastal elevation areas in Louisiana, and model and understand the ramifications of predicted sea-level rise. To accomplish these objectives, the study made use of accessible public datasets to assess the potential risk faced by residents of coastal lowlands of Southern Louisiana in the United States. Elevation data was obtained from the Louisiana Statewide Light Detection and Ranging (LiDAR) with resolution of 16.4 feet $(5 \mathrm{~m})$ distributed by Atlas. The data was downloaded from Atlas website and imported into Environmental Systems Research Institute's (ESRI's) ArcMap software to create a single mosaic elevation image map of the study area. After mosaicking the elevation data in ArcMap, Spatial Analyst extension software was used to classify areas with low and high elevation. Also, data was derived from United States Geological Survey (USGS) Digital Elevation Model (DEM) and absolute sea level rise data covering the period 1880 to 2015 was acquired from United States Environmental Protection Agency (EPA) website. In addition, population data from U.S. Census Bureau was obtained and coupled with elevation data for assessing the risks of the population residing in low lying areas. Models of population trend and cumulative sea level rise were developed using statistical methods and software were applied to reveal the national trends and local deviations from the trends. The trends of population changes with respect to sea level rise and
\end{abstract}


time in years were modeled for the low land coastal parishes of Louisiana. The expected years for the populations in the study area to be at risk due to rising sea level were estimated by models. The geographic information systems (GIS) results indicate that areas of low elevation were mostly located along the coastal Parishes in the study area. Further results of the study revealed that, if the sea level continued to rise at the present rate, a population of approximately 1.8 million people in Louisiana's coastal lands would be at risk of suffering from flooding associated with the sea level having risen to about 740 inches by 2040 . The population in high risk flood zone was modeled by the following equation: $y=6.6667 x-12,864$, with $\mathrm{R}$ squared equal to 0.9964 . The rate of sea level rise was found to increase as years progressed. The slopes of models for data for time periods, 1880-2015 (entire data) and 1970-2015 were found to be, 4.2653 and 6.6667, respectively. The increase reflects impacts of climate change and land management on rate of sea level rise, respectively. A model for the variation of years with respect to cumulative sea level was developed for use in predicting the year when the cumulative sea level would equal the elevation above sea level of study area parishes. The model is given by the following equation: $y=0.1219 x+1944.1$ with $\mathrm{R}$ square equal to 0.9995 .

\section{Keywords}

Coastal Flooding, Climate Change, Sea Level Rise, Elevation, Global Warming, GIS, Population, Regression Analysis, Louisiana

\section{Introduction}

In the last few decades there had been calls by various governments, environmentalist, journalist and non-governmental organizations for the world to reduce greenhouse gases because of their contribution to global warming and the accompanying risks to the population [1] [2]. The 1992 United Nations Conference on Environment and Development (UNCED) in Brazil also known as the Rio Conference and Earth Summit highlighted the severity of the environment and the need to promote sustainable development in order to reduce greenhouse gases [3]. The goal of the UNECD was to seek common action to protect the planet from environmental degradation that threatens to change the global climate. It also aimed to increase national and international efforts to promote sustainable and environmentally sound development in all countries [3] [4]. The conference culminated in the signing of the 1992 Earth Summit. Following the signing of the 1992 Earth Summit, Kyoto protocol emerged from the UN Framework Convention on Climate Change (UNFCCC) with the legally binding agreement under which the industrialized countries were asked to reduce their collective emissions of greenhouse gases by 5.2\% [5] [6]. The recent Paris Agreement, signed in 2015 by 175 parties, also aimed to limit global warming to below $2^{\circ} \mathrm{C}$ compared to pre-industrial levels. It focuses on reducing greenhouse 
gas emissions, and to provide financial assistance to developing countries affected by a changing climate [7] [8].

\section{Emissions, Climate Change, and Sea Level Rise Projections}

Human activities play an important role in emissions release in the atmosphere, causing global temperatures to rise, warm the oceans and deplete the biodiversity [9] [10] [11]. According to U.S. Environmental Protection Agency (EPA) data in 2019, global $\mathrm{CO}_{2}$ emissions from fossil fuels have been increasing at an alarming rate since 1900 [12]. For example, Olivier et al. 2015 and 2016 reports on trends in global $\mathrm{CO}_{2}$ emissions among the Organization for Economic Co-operation and Development (OECD) countries in Europe and Asia, show higher emissions in thousands of tons per annum in 2013 [13] [14]. In the developing countries deforestation caused by slash-and-burn agriculture and fuel wood burning are important sources of carbon dioxide emissions, whereas cattle raising, and rice cultivation are important sources of methane. According to (Borroto, 1997), other stressors such as ammonia-based fertilizers and solvents, refrigerants and forming agents contribute to nitric oxide and chlorofluorocarbon. These and other sources are thought to be enhancing greenhouse effect leading to global warming [15]. In the United States, U.S. EPA reported that $\mathrm{CO}_{2}$ emissions from the burning of fossil fuel for energy, transportation and electricity production constituted 77 percent of all U.S. man-made greenhouse-gas emissions in 2018 [16].

The positive correlation between global climate change and sea level rise has been well-documented and gained attention by many scientists [17]-[30]. Rising global temperatures from climate change are leading causes of sea level rise. There are numerous projections around the globe on sea level rise. The National Research Council [31], projected average Sea Level Rise along California coast south and north of Cape Mendocino in year 2030 will be 6 inches and 2 inches, respectively. Similar projection in the year 2050 shows sea level rise in south of Cape Mendocino will increase to 12 inches and 6 inches in the south and north respectively. The National Oceanic and Atmospheric Administration (NOAA) scientist, Linsey [26], projected that by the end of the century, global mean sea level (GMSL)would rise at least one foot ( 0.3 meters) above 2000 levels by 2100 [26]. In Europe, Vousdoukas et al. [32] study along European coasts, projected that by the end of this century, extreme sea levels (ESLs) along Europe's coastlines will increase by $57 \mathrm{~cm}$ (equivalent to 1.87 feet) for Representative Concentration Pathways (RCP) 4.5 and $81 \mathrm{~cm}$ (equivalent to 2.66 feet) for RCP8.5. Accordingly, their projection for North Sea region is slated to face the highest increase in ESLs, amounting to almost $1 \mathrm{~m}$ (equivalent to 3.28 feet) under RCP8.5 by 2100 . The most recent and comprehensive projections for future sea-level rise are presented in the 2019 United Nation's Intergovernmental Panel on Climate Change (IPCC) report on the Ocean and Cryosphere in a Changing Climate (SROCC) [33]. According to the report, Global Mean Sea Level (GMSL) will rise 
between 1.41 feet $(0.43 \mathrm{~m})(0.29-0.59 \mathrm{~m}$, likely range; RCP2.6) and 2.76 feet $(0.84 \mathrm{~m})(0.61-1.10 \mathrm{~m}$, likely range; RCP8.5) by 2100 [33]. Beyond 2100, according to the report sea level will continue to rise for centuries due to continuing deep ocean heat uptake and mass loss of the Greenland Ice Sheet (GIS) and Antarctic Ice Sheet (AIS). IPCC's earlier report in 2007 projected an estimate of $60 \mathrm{~cm}(2 \mathrm{ft})$ through 2099, but their 2014 report estimated about $90 \mathrm{~cm} \mathrm{(3 \textrm {ft } )}$ [34]. It is important to note that both projections by Vousdoukas et al. [32] and IPCC, [33] incorporated into their analysis the global carbon emissions Representative Concentration Pathways (RCP) with RCPs of 2.6 means (low emissions), 4.5 (moderate emissions), and 8.5 (high emissions). In North Atlantic Ocean, Slangen et al. [35] estimated mass-changes in land-ice from model-based projections of temperature and precipitation. The models and assumptions employed by this study suggested that global mean sea-level rise would be about $0.54 \pm 0.19 \mathrm{~m}$ and $0.71 \pm 0.28 \mathrm{~m}$ respectively for both warmer and moderate climate change with regional changes of up to $30 \%$ higher in coastal regions along the North Atlantic ocean; and up 20\% higher in the subtropical and equatorial regions [35].

\section{Models Used in Assessing Risks of Population Living in Low-Lying Coastal Areas}

In event of sea level rise resulting from climate change, many coastal populations located in low elevation areas would be at risk. These phenomena could lead to flooding, displacement of the population and destruction of coastal ecosystems and eliminate wetlands, and biodiversity [36] [37]. Climate Central [38] estimates that in the event of climate change, inundated cities in low elevation coastal areas could cost trillions of dollars in economic losses and damages each year if rigorous adaptation plans are not implemented. Several studies have utilized quantitative models and approaches to investigate and assess risks of population residing in coastal lowlands that are vulnerable to risks resulting from climate change. Majority of these studies are centered on risks involving economic and human-based methods to assess the risks and economic impacts on the population including the one residing in these low elevation areas [39] [40] [41]. However, quantifications of risks of climate change and human settlements in low elevation coastal zones in Louisiana combining population, elevation and absolute sea level rise data have not been extensive. Therefore, the objective of this paper is to identify high risk areas that are prone to high impact of climate change and human settlements in low-lying coastal elevation areas in Southern Louisiana and to model and understand the ramifications of predicted sea-level rise.

\section{Methodology}

\subsection{The Study Area}

Flooding is one of the major problems facing Louisiana. For the past 10 years 
there has been a major issue of coastal flooding due to low coastal elevation. This problem has been enhanced by climate change. The recent floods in August 2016, destroyed parts of surrounding coastal areas in southern Louisiana. For a period exceeding 10 years, these parishes have suffered several natural disasters related to flooding such as storms, tropical cyclones, and hurricanes [42] [43]. The disasters have been accompanied by loss of human life and millions of dollars' worth of properties [43]. In 2005 for instance, many lives, enterprises and homes worth billions of dollars were lost because of the impact of Hurricane Katrina floods [44] [45]. A chronology of Louisiana's tropical hurricanes and storms and corresponding impacts (1997-2005) is presented in Table 1. Most of the parishes listed as low elevation have elevations lower than 30 feet above sea level. Population change vis-à-vis the elevation above the sea was studied. The elevations above the sea level for all the low land parishes were lower than 40 feet. The map of the study area with all its parishes is presented in Figure 1. Figure 2 represents an interactive map of land projected to be below tideline in 2050 using Coastal DEM. The parishes located at base of Louisiana, bordering the ocean and their immediate neighbors are low elevation parishes. The coastal parishes are Cameron, Vermilion, Iberia, St. Mary, Terrebonne, Lafourche, Jefferson, Plaquemine, St. Benard, Orleans, and Orleans. Table 2 illustrates the parishes and their corresponding populations.

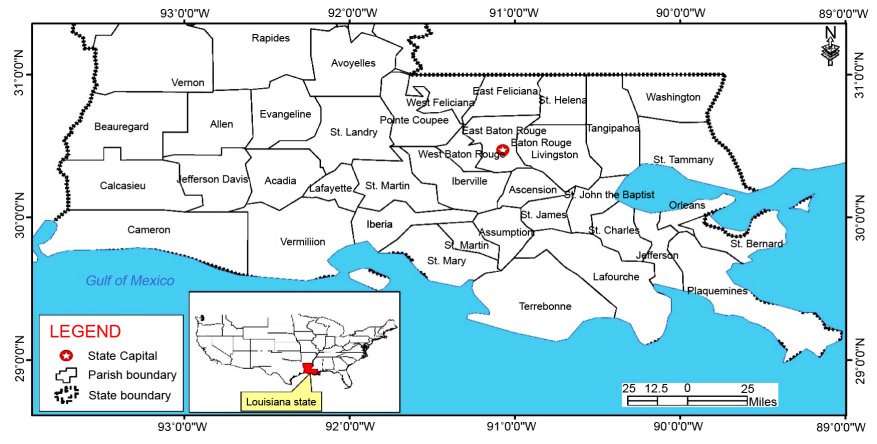

Figure 1. Study area: South of latitude $31^{\circ} \mathrm{N}$ with northern boundary parishes below: Washington, Tangipahoa, Helena, Feliciana, East Feliciana, West Feliciana, Pointee Coupee, St. Landry, Evangeline, Allen and Beauregard.

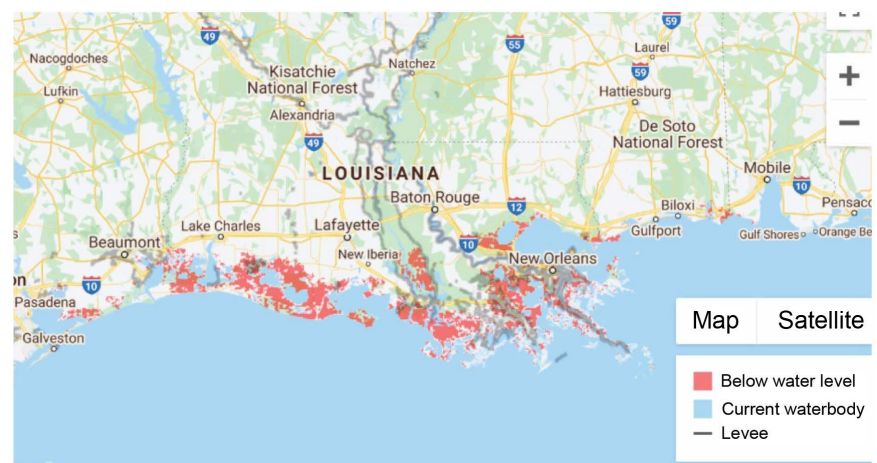

Figure 2. An interactive map of land projected to be below tideline in 2050 using Coastal DEM. Source: Coastal central (assessed on February 20, 2020) [51]. 
Table 1. Louisiana tropical hurricanes and storms and their impacts (1997-2005) [46] [47] [48] [49] [50].

\begin{tabular}{|c|c|c|}
\hline Year & Name & Impact \\
\hline 1992 & $\begin{array}{l}\text { Hurricane Andrew, Cat. } 4 \text { across Florida, } \\
\text { Cat. } 3 \text { upon landfall in Louisiana }\end{array}$ & $\begin{array}{l}17 \text {-foot storm surge in Florida, } 8 \text {-foot storm tide in Louisiana, } \\
23 \text { deaths nationwide, } \$ 26.5 \text { billion in damages nationwide; } \\
\$ 1 \text { billion in Louisiana and } \$ 25.5 \text { billion in Florida }\end{array}$ \\
\hline 1997 & $\begin{array}{l}\text { Hurricane Danny, Cat. 1, Landfall in Louisiana, } \\
\text { Tropical Storm over Florida }\end{array}$ & 4 deaths nationwide, $\$ 100$ million in total damages nationally \\
\hline 1998 & Tropical Storm Hermine, Landfall in Louisiana & No information \\
\hline 2001 & Tropical Storm Allison, Landfall in Louisiana & $\begin{array}{l}\text { Excessive rain-up to } 30 \text { inches in places, } 23 \text { tornadoes across the Southeast, } \\
41 \text { deaths nationwide. } \$ 5 \text { billion in damages nationwide }\end{array}$ \\
\hline 2002 & Tropical Storm Bertha, Landfall in Louisiana & $\begin{array}{l}\text { 3- to } 4 \text {-foot storm tides, Heavy rains; } 3 \text { - } 6 \text { inches across Louisiana, } \\
\text { No monetary damage figures available }\end{array}$ \\
\hline 2002 & Tropical Storm Hanna, Landfall in Louisiana & 5 - 10 inches of rain across southeast states, $\$ 20$ million in damages nationwide \\
\hline 2002 & Tropical Storm Bertha, Landfall in Louisiana & $\begin{array}{l}\text { 3- to } 4 \text {-foot storm tides, Heavy rains; } 3 \text { - } 6 \text { inches across Louisiana, } \\
\text { No monetary damage figures available }\end{array}$ \\
\hline 2002 & Tropical Storm Hanna, Landfall in Louisiana & 5 - 10 inches of rain across southeast states, $\$ 20$ million in damages nationwide \\
\hline 2003 & Tropical Storm Bill, Land-fall in Louisiana & 4 deaths, $\$ 50$ million in damages nationwide \\
\hline 2004 & $\begin{array}{l}\text { Hurricane Ivan, Cat. 4, Tropical storm across } \\
\text { East Coast that looped back to Louisiana }\end{array}$ & $\begin{array}{l}10 \text { - to } 15 \text {-foot storm surge, } 10-15 \text { inches of rain, } 25 \text { deaths in the United States, } \\
\$ 14.2 \text { billion in damages nation }\end{array}$ \\
\hline 2004 & Tropical Storm Matthew & Heavy rains, 6-foot storm surge, No information on damages available \\
\hline 2005 & Hurricane Cindy, Cat. 1, Landfall in Louisiana & $\begin{array}{l}\text { 4- to 6-foot storm surge, } 33 \text { tornadoes across the east as system moved north, } \\
\text { Heavy rains across all eastern states, } 1 \text { death, } \$ 320 \text { million } \\
\text { in damages nationwide }\end{array}$ \\
\hline 2005 & $\begin{array}{l}\text { Hurricane Katrina, Cat. 5, Cat. } 1 \text { across Florida, } \\
\text { Cat. } 3 \text { in Louisiana }\end{array}$ & $\begin{array}{l}\text { 10- to } 20 \text {-foot storm surge in Louisiana; storm surge penetrated } 6 \text { miles inland } \\
\text { in some locations of Louisiana, } 28 \text {-foot storm tide reported in Mississippi, } \\
11 \text { - } 14 \text { inches of rain in Dade County, Florida; } 8 \text { - } 10 \text { inches across Louisiana, } \\
33 \text { reported tornadoes, } 1,336 \text { known deaths nationwide, } \\
\$ 40 \text { - } 120 \text { billion in damages nation-wide }\end{array}$ \\
\hline 2005 & $\begin{array}{l}\text { Hurricane Rita, Cat. } 5 \text {, } \\
\text { Cat. } 3 \text { before landfall in Louisiana }\end{array}$ & $\begin{array}{l}\text { 4- to } 7 \text {-foot storm surge (gauge); } 8 \text { - to } 12 \text {-foot storm surge (visual evidence); } \\
\text { 4- to } 5 \text {-foot storm surge in Florida Keys, } 90 \text { tornadoes, } \\
7 \text { deaths } \$ 10 \text { billion in damages nationwide }\end{array}$ \\
\hline 2005 & Tropical Storm Tammy, Landfall in Florida & 2- to 4 -foot storm surge, 3 - 5 inches of rain, $\$ 25$ million in damages nation-wide \\
\hline
\end{tabular}

Table 2. Human population data for Louisiana coastal parishes for the period 1970-2020. Human population data for Louisiana coastal parishes for the period 1970-2020 [52] [53].

\begin{tabular}{|c|c|c|c|c|c|c|c|c|c|}
\hline \multirow{2}{*}{ Parish } & \multirow{2}{*}{1970} & \multirow{2}{*}{1980} & \multirow{2}{*}{1990} & \multirow{2}{*}{2000} & \multirow{2}{*}{2010} & \multirow{2}{*}{2020} & \multirow{2}{*}{$\begin{array}{c}\text { \% Change } \\
(1990-2000)\end{array}$} & \multirow{2}{*}{$\begin{array}{c}\% \text { Change } \\
(2000-2010)\end{array}$} & \multirow{2}{*}{$\begin{array}{c}\text { \% Change } \\
(2010-2020)\end{array}$} \\
\hline & & & & & & & & & \\
\hline Orleans & 115,387 & 139,241 & 496,938 & 484,674 & 351,222 & 391,006 & -2.4679135 & -27.534384 & 11.3273087 \\
\hline St. Bernard & 51,186 & 64,097 & 66,631 & 67,229 & 37,764 & 46,721 & 0.89748015 & -43.827812 & 23.7183561 \\
\hline La Fourche & 68,941 & 82,483 & 85,860 & 60,255 & 62,054 & 98,115 & -29.821803 & 2.98564434 & 58.1122893 \\
\hline Plaquemines & 25,225 & 26,049 & 25,575 & 26,757 & 25,106 & 23,410 & 4.62170088 & -6.1703479 & -6.7553573 \\
\hline Terrebonne & 76,049 & 94,393 & 96,982 & 72,392 & 77,923 & 111,021 & -25.355221 & 7.640347 & 42.475264 \\
\hline Jefferson & 338,229 & 454,592 & 448,306 & 438,731 & 417,828 & 434,051 & -2.1358179 & -4.7644228 & 3.88269814 \\
\hline Iberia & 57,397 & 63,752 & 68,297 & 73,266 & 73,240 & 70,941 & 7.27557579 & -0.0354871 & -3.1389951 \\
\hline St. Mary & 60,752 & 64,253 & 58,086 & 53,500 & 54,650 & 49,774 & -7.8951899 & 2.14953271 & -8.9222324 \\
\hline Vermilion & 43,071 & 48,458 & 50,055 & 53,807 & 57,999 & 59,830 & 7.49575467 & 7.79080789 & 3.15695098 \\
\hline Cameron & 8194 & 9336 & 9260 & 9991 & 6839 & 6968 & 7.89416847 & -31.548394 & 1.88624068 \\
\hline Total & 844,431 & $1,046,654$ & $1,405,990$ & $1,340,602$ & $1,164,625$ & $1,291,837$ & -4.6506732 & -13.126715 & 10.923001 \\
\hline
\end{tabular}




\subsection{Data Acquisition}

Elevation data was obtained from the Louisiana Statewide Lidar distributed by Atlas with resolution of 16.4 feet $(5 \mathrm{~m})$ and downloaded from their website [54]. Maps and GIS imagery were used to locate and determine the corresponding elevations above sea level for coastal low land parishes of Louisiana. Kosovich's data [55] derived from USGS Digital Elevation Data was used for this study. Population data from U.S. Census was also used for this study is shown in Table 2. The absolute sea level rise data covering the period 1880 to 2015 was also obtained from U.S. Environmental Protection Agency (EPA) website [56]. Summary of data sources for this paper is presented in Table 3.

\subsection{Data Analysis}

To process the Lidar DEM, each tile in the study area Parishes below South of Latitude $31^{\circ} \mathrm{N}$ were downloaded and imported into ESRI ArcMap software to create a single mosaic elevation image of the study area (Figure 1). After mosaicking the elevation data in ArcMap, Spatial Analyst extension software was used to classify areas with low and high elevation. Population trends and trends with respect to sea level rise were modeled for the study area composed of the low land coastal parishes. The years when parishes would be at risk of flooding were estimated by models. Before analysis of the results, mathematical formulation was presented. The total human population for low land parishes (Cameron, Vermilion, Iberia, St. Mary, Terrebonne, Lafourche, Jefferson, Plaquemine, St. Benard, Orleans and Orleans) was modeled with respect to years to predict the parishes' population by the year 2040 by regression, using Microsoft Excel statistical analysis tool kit.

The data used to compute the total human population for these parishes was derived from the human population data for Louisiana coastal parishes for the period 1970-2020 (Table 2). The data is presented in Table 4.

Third order polynomial curve fitting was used to model the 1970-2020 data, followed by extrapolation to 2040, with the help of the Microsoft Excel statistical tool kit. The model is illustrated in Figure 3. It represents about $83 \%$ of the population data variation $(\mathrm{R}$ squared $=0.83$ ).

Table 3. Summary of data sources.

\begin{tabular}{|c|c|c|c|c|}
\hline Dimension & Dataset Name & Unit & Resolution & Source(s) \\
\hline Elevation & LiDAR DEM & Meters & $5 \mathrm{~m}$ (16.4 feet) & Atlas: https://maps.ga.lsu.edu/lidar2000/ \\
\hline Elevation & $\begin{array}{c}\text { Map of LA } \\
\text { Low-Lying Areas }\end{array}$ & Feet & & $\begin{array}{c}\text { Kosovic (2008) and USGS: } \\
\text { https://pubs.usgs.gov/sim/3049/downloads/SIM3049.pdf }\end{array}$ \\
\hline Population & LA Population & & & $\begin{array}{c}\text { U.S. Census Bureau } 2010 \\
\frac{\text { https://www.census.gov/prod/cen2010/cph-2-20.pdf }}{\text { World Population Review2019 }} \\
\text { http://worldpopulationreview.com/us-counties/la/ }\end{array}$ \\
\hline $\begin{array}{l}\text { Sea } \\
\text { Level } \\
\text { Rise }\end{array}$ & $\begin{array}{l}\text { Global Absolute } \\
\text { sea level rise data } \\
1880-2015\end{array}$ & Inches & & $\begin{array}{c}\text { U.S. EPA's Climate Change Indicators } \\
\text { https://www.epa.gov/sites/production/files/2016-08/sea-level_fig-1.csv }\end{array}$ \\
\hline
\end{tabular}




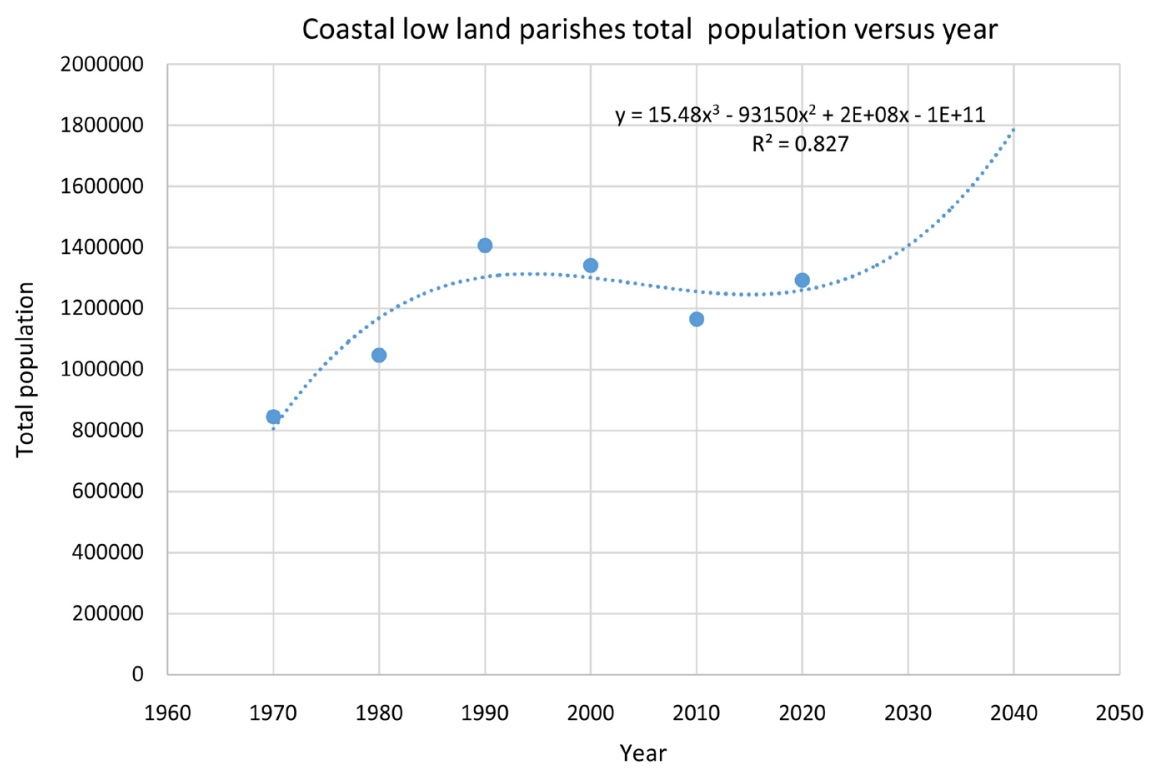

Figure 3. Total human population in Louisiana's coastal parishes 1970-2040.

Table 4. Total population for southeastern Louisiana low land coastal parishes, 1970-2020.

\begin{tabular}{cc}
\hline Year & Population \\
\hline 1970 & 844,431 \\
1980 & $1,046,654$ \\
1990 & $1,405,990$ \\
2000 & $1,340,602$ \\
2010 & $1,164,625$ \\
2020 & $1,291,837$ \\
\hline
\end{tabular}

The population in these parishes rose from about 800,000 in 1970 to a number between 1.4 and 1.2 million in 1990. It then dropped to almost 1.2 million by 2010. After 2010 it began to rise. According to the model, the coastal low land parishes will be harboring a human population of about 1.8 million by 2040 .

The absolute sea level rise data is available for the period 1880 to 2015 [56]. The annual cumulative sea level rise above the datum level of 1980 was computed from the absolute sea level change data and presented as illustrated in $\mathrm{Ta}$ ble 5 .

The models for rise in sea level and time, $t$ in years were modeled based on the following logic and formulations. In the following formulation, extra water refers to quantity of water more than quantity required to maintain global sea level constant.

When glaciers and snow in mountains etc. melt because of global warming, water formed contributes to increase in the global water cycle. Water in liquid phase flows to regions of lower elevation. The molten ice contributes to increase in global sea level as illustrated in the following word equation.

Extra water flowing into global sea $\propto$ Mass of molten snow 
Table 5. The annual cumulative sea level rise above the datum level from Global Average Absolute Sea Level Change, 1880-2015 [56].

\begin{tabular}{|c|c|c|c|c|c|c|c|}
\hline $\begin{array}{l}\text { Cumulative } \\
\text { sea level/in }\end{array}$ & Year & $\begin{array}{l}\text { Cumulative } \\
\text { sea level/in }\end{array}$ & Year & $\begin{array}{l}\text { Cumulative } \\
\text { sea level/in }\end{array}$ & Year & $\begin{array}{l}\text { Cumulative } \\
\text { sea level/in }\end{array}$ & Year \\
\hline 0 & 1880 & 53.45275586 & 1914 & 169.9999999 & 1948 & 347.8425194 & 1982 \\
\hline 1.173228345 & 1881 & 56.09448814 & 1915 & 173.8425195 & 1949 & 354.2874012 & 1983 \\
\hline 1.637795274 & 1882 & 58.63779522 & 1916 & 177.7519683 & 1950 & 360.688976 & 1984 \\
\hline 2.303149604 & 1883 & 60.99606293 & 1917 & 182.0314959 & 1951 & 366.685039 & 1985 \\
\hline 3.767716532 & 1884 & 73.28740151 & 1918 & 186.2047242 & 1952 & 372.7047241 & 1986 \\
\hline 5.161417318 & 1885 & 75.64173222 & 1919 & 190.5433069 & 1953 & 378.7440941 & 1987 \\
\hline 6.417322829 & 1886 & 78.05905505 & 1920 & 194.7598423 & 1954 & 384.9724406 & 1988 \\
\hline 7.452755899 & 1887 & 80.56299206 & 1921 & 199.0039368 & 1955 & 391.3818894 & 1989 \\
\hline 8.570866134 & 1888 & 83.035433 & 1922 & 203.0433069 & 1956 & 397.8740154 & 1990 \\
\hline 9.751968495 & 1889 & 85.54724402 & 1923 & 207.606299 & 1957 & 404.4685036 & 1991 \\
\hline 11.00787401 & 1890 & 87.77559047 & 1924 & 212.2125982 & 1958 & 411.0905508 & 1992 \\
\hline 12.19685038 & 1891 & 90.10236213 & 1925 & 216.8267715 & 1959 & 417.3818894 & 1993 \\
\hline 13.51181101 & 1892 & 92.6889763 & 1926 & 231.590551 & 1960 & 423.6927625 & 1994 \\
\hline 14.99606298 & 1893 & 95.20078732 & 1927 & 236.598425 & 1961 & 430.1847071 & 1995 \\
\hline 16.14960629 & 1894 & 97.53543298 & 1928 & 241.4015746 & 1962 & 436.8352397 & 1996 \\
\hline 17.76771652 & 1895 & 99.91732275 & 1929 & 246.1417321 & 1963 & 443.5752737 & 1997 \\
\hline 19.07086613 & 1896 & 102.4527558 & 1930 & 250.5748029 & 1964 & 450.4403041 & 1998 \\
\hline 20.56299211 & 1897 & 114.9803149 & 1931 & 255.4488187 & 1965 & 457.2839363 & 1999 \\
\hline 22.38188974 & 1898 & 117.7204723 & 1932 & 260.106299 & 1966 & 464.1897284 & 2000 \\
\hline 24.48425195 & 1899 & 120.6259842 & 1933 & 264.8149604 & 1967 & 471.2477312 & 2001 \\
\hline 26.33070864 & 1900 & 123.3228345 & 1934 & 269.5629919 & 1968 & 478.5377396 & 2002 \\
\hline 28.13385824 & 1901 & 126.2401574 & 1935 & 274.5905509 & 1969 & 485.9993531 & 2003 \\
\hline 30.10629919 & 1902 & 128.9999999 & 1936 & 279.5433068 & 1970 & 493.4732166 & 2004 \\
\hline 32.38188973 & 1903 & 131.9842519 & 1937 & 284.6968501 & 1971 & 501.0793839 & 2005 \\
\hline 34.24803146 & 1904 & 135.070866 & 1938 & 290.2086612 & 1972 & 508.7313949 & 2006 \\
\hline 35.83858264 & 1905 & 138.3779526 & 1939 & 295.4803147 & 1973 & 516.3899859 & 2007 \\
\hline 37.6692913 & 1906 & 141.4330707 & 1940 & 301.2204722 & 1974 & 524.2527581 & 2008 \\
\hline 39.45275587 & 1907 & 144.9566928 & 1941 & 306.8937005 & 1975 & 532.245842 & 2009 \\
\hline 41.12204721 & 1908 & 148.4803148 & 1942 & 312.5314958 & 1976 & 540.3116984 & 2010 \\
\hline 42.9724409 & 1909 & 152.0039369 & 1943 & 318.0944879 & 1977 & 548.2885767 & 2011 \\
\hline 44.8188976 & 1910 & 155.2716534 & 1944 & 323.9133855 & 1978 & 556.685954 & 2012 \\
\hline 46.97637791 & 1911 & 158.6496062 & 1945 & 329.5393698 & 1979 & 565.1704963 & 2013 \\
\hline 49.01181098 & 1912 & 162.3188975 & 1946 & 335.3937005 & 1980 & 573.7688199 & 2014 \\
\hline 51.11417318 & 1913 & 166.070866 & 1947 & 341.7362202 & 1981 & 582.7121276 & 2015 \\
\hline
\end{tabular}


Extra water flowing into global sea $=K^{\star}$ Mass of molten snow

Hence, increase in global sea volume ${ }^{\star}$ average density of sea water $=K^{\star}$ Mass of molten ice

$\Rightarrow($ Global sea area + change in global area of sea $){ }^{\star}$ rise in sea level $=K^{\star}$ Mass of molten snow

The quantity of molten ice is a function of temperature, $T$ and duration time, $t$.

Since the change in sea level is proportional to the quantity of molten ice, which is proportional to duration time, $t$, it follows that the rise in sea level is a function of time, $t$ [57].

In modelling the variation between the cumulative level, $H$ and time, regression was used.

Rise in sea level, $H \propto f(t)$

For cubic model,

$$
H=A_{n+1} t^{n}+A_{n} t^{n-1}+A_{n-1}+t^{n-2}+A_{n-2}
$$

where, $H$ is the cumulative sea level in units of length, $n$ is the polynomial index, 3 and $t$ is time in years.

For quadratic model,

$$
H=A_{n+1} t^{n}+A_{n} t^{n-1}+A_{n-1}+t^{n-2}+A_{n-2}
$$

where, $H$ is the cumulative sea level in units of length, $n$ is the polynomial index, 2 and $t$ is time in years.

For linear model,

$$
H=A_{n} t+A_{n+1}
$$

where, $H$ is the cumulative sea level in units of length, $n$ is 1 and $t$ is time in years.

Sea level data from EPA's Global Average Absolute Sea Level Change, 1880-2015 [56] was fitted to the proposed models by regression, using statistical software (SPSS, Microsoft Excel data analysis toolkit). The equation and $\mathrm{R}$ squared, were determined. The strength of model developed was based on the magnitude of the coefficients of correlations between variables ( $R$ square). The linear model developed is presented in Figure 4.

However, from the scatter diagram the rate of sea level rise with respect to years was observed to increase as years progressed. Hence, to determine the anticipated sea level rise based on the current rate of increase, Microsoft Excel statistical tool kit was used to predict sea level rise with respect to time (years), using the sea level rise data of 1970-2015. This data was extracted from the 1880-2015 data. Regression analysis curve fitting was used. The regression line was extrapolated to the year 2020 using Microsoft Excel statistical tool kit. According to the linear model illustrated in Figure 4, the cumulative sea level rise from 1880 to 2020 is 600 inches. The model represents $86 \%$ of the data's variation $(\mathrm{R}$ squared $=0.9964)$. 


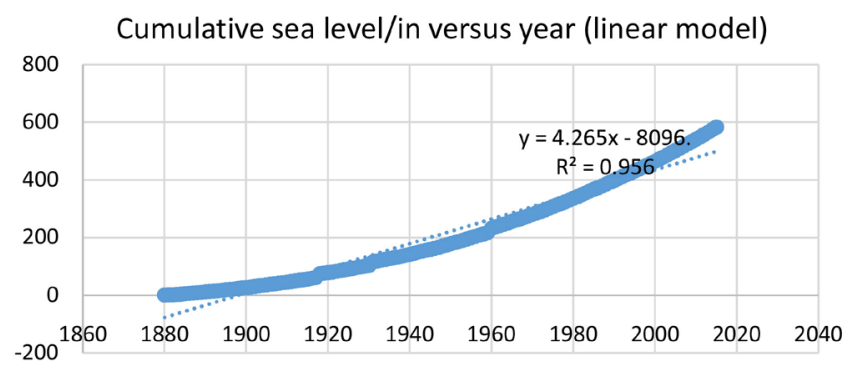

Figure 4. Sea level rise versus year with respect to 1880 (1880-2020).

\section{Results and Discussion}

The model illustrated in Figure 5 was extrapolated to 2040 by forwarding the year variable by 20 using Microsoft Excel. The prediction of sea level rise is illustrated in the following graph (Figure 6). Results of classified LiDAR DEM are shown in Figure 6 and Figure 8. From Figure 2, Figure 7, and Figure 8, most of the study area in the southern section of the state lies below sea level. With the area experiencing some growth in population from 1,164,625 million (Table 2), between 2010 and 2020 respectively, the vulnerability of coastal ecosystems to sea level rise could increase. This could have extreme impacts on both the natural and built up environments particularly around big cities holding vital infrastructure crucial in economic development and productive capacity of petroleum and natural resource assets of South of Louisiana. While the situation is further compounded by the region's propensity to natural disasters and the fragile coastal ecosystem close to enormous network of large-scale energy infrastructure made up of oil and gas fields, refineries, and pipeline. The presence of petrochemical complexes, thriving natural resource base, transportation corridors, burgeoning urban centers and neighborhoods often at the receiving end of recurrent climate hazards over time accentuates the inherent risks, due to environmental, physical, and socio-economic and policy factors located within the larger regional ecosystem.

The model illustrated in Figure 6 suggests that when the population will be 1.8 million, the cumulative (absolute) sea level will be 740 inches by 2040 .

To appreciate the risk of sea level rise to residents of the Louisiana low land parishes, Microsoft Excel statistical tool kit was used to model population versus sea level rise by curve fitting. In this modeling exercise, the total population data (1970-2040) and sea level data (1880-2015) were used. Absolute (cumulative) sea level used in modeling. The model is illustrated in Figure 9.

According to the model the total population in these parishes rose from about 800,000 when the sea level was less than 300 inches to almost 1.4 million despite the sea level rising from less than 300 inches to about 450 inches. It then began to drop as the sea level rose. Between 500 inches and 600 inches sea levels, the total population in coastal parishes began to rise again while the sea level continued to rise. Hence, as the sea level rises, the population in these lands. The number of people at risk is on the rise. The correlation coefficient between the absolute sea level rise and population growth in the low land parishes is $89 \%$ (Figure 9). 


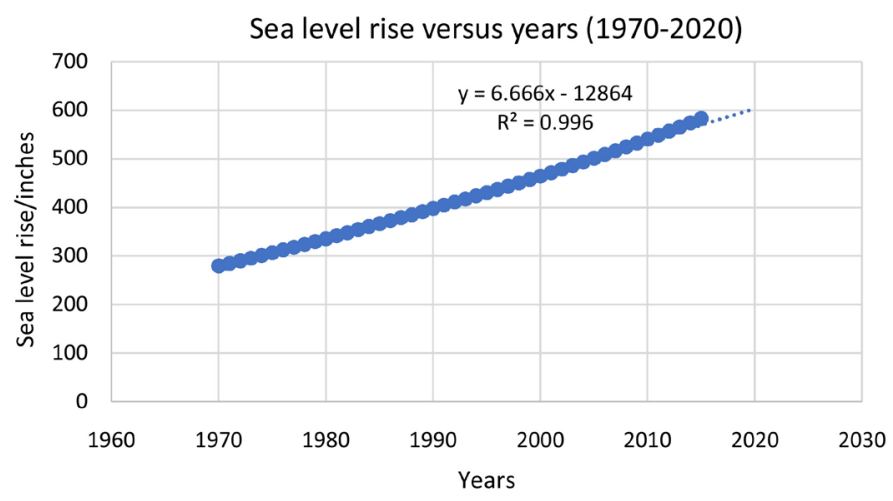

Figure 5. Sea level rise versus year with respect to 1880 (1970-2020).

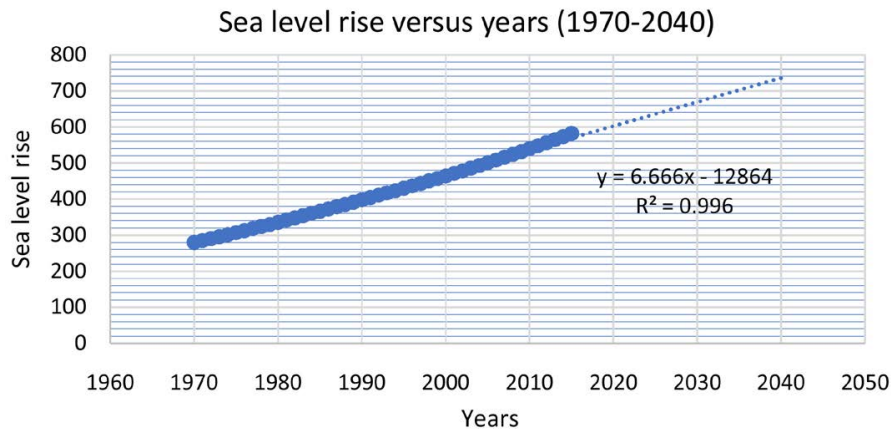

Figure 6. Sea level rise versus year with respect to 1880 (1970-2040).

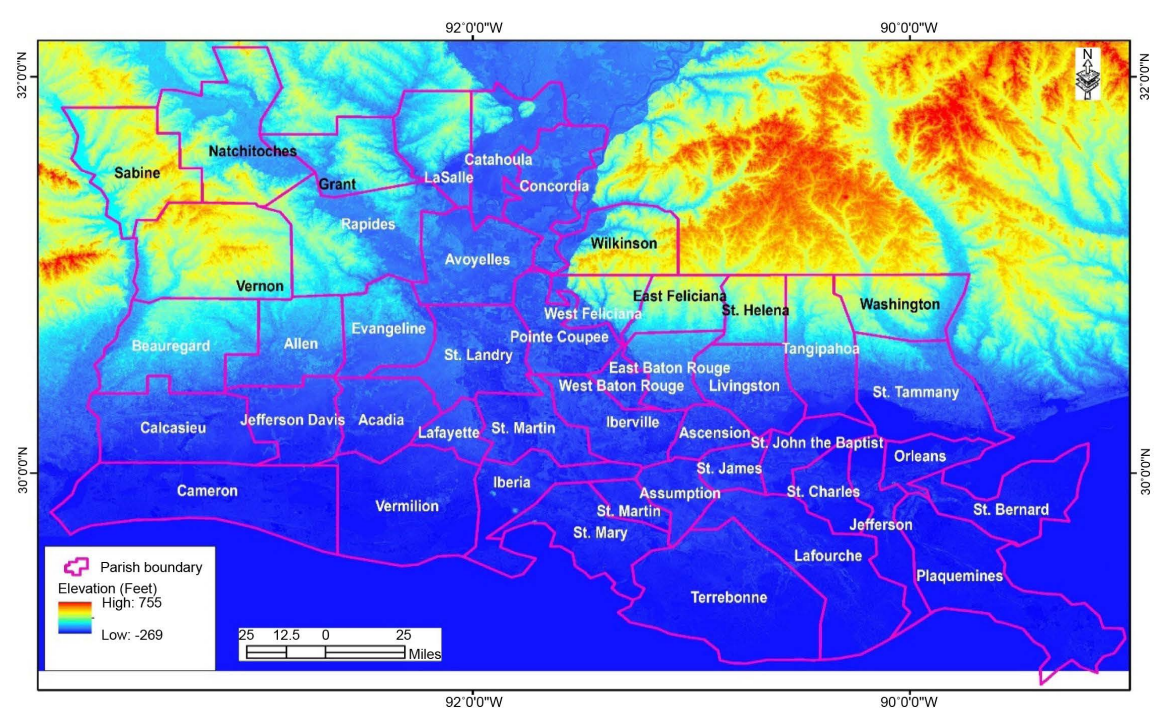

Figure 7. Classified elevation map of the study area.

Next the expected number of years it would take for the sea level to rise and equal the elevations of coastal parishes above the sea level were determined. First a model was developed for (time) years versus time sea level rise (inches) using all the data downloaded from Global Average Absolute Sea Level Change, 1880-2015 (2019). This was carried out by regression analysis using Microsoft Excel statistical tool kit. The model is illustrated in Figure 10. 


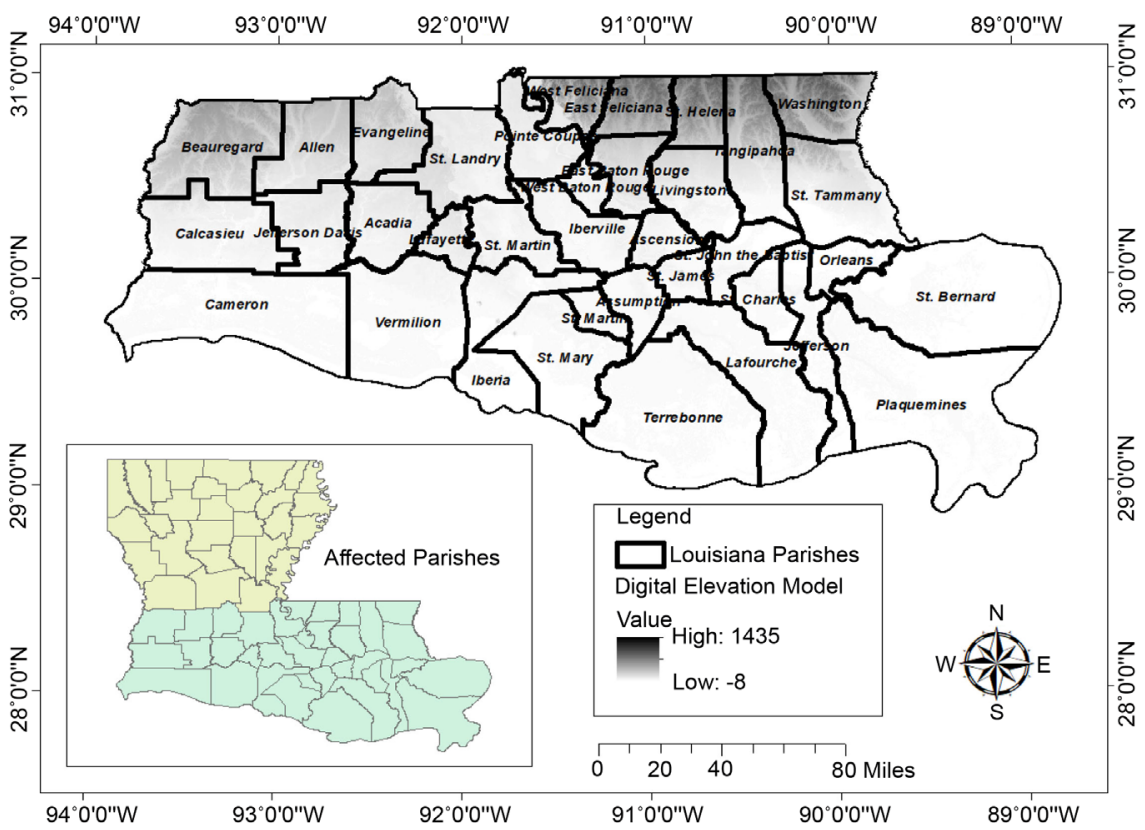

Figure 8. Classified elevation map of the study area in the shades of gray color.

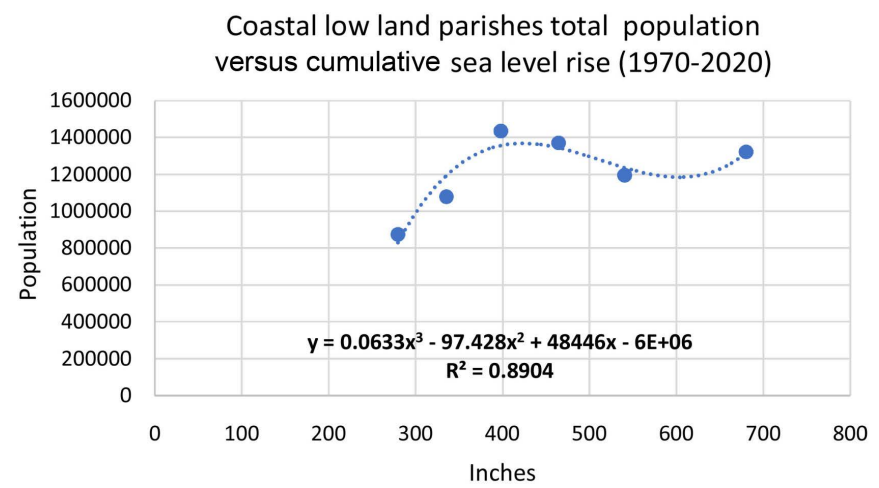

Figure 9. Variation between total population in low land parishes and cumulative sea level rise.

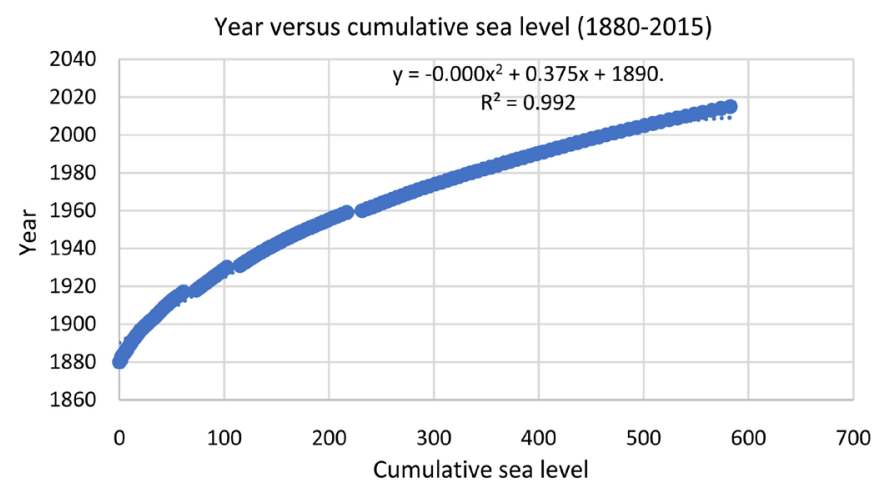

Figure 10. Years versus cumulative sea level (quadratic model).

Although the quadratic model illustrated in Figure 10 looks very suitable for modeling the year with respect to sea level rise, the model starts to yield drops in 
years for increasing sea level rises after its maximum value. To determine the magnitude of sea level corresponding to the maximum value of years for the model, the model is differentiated with respect to the cumulative sea level and the derivative equated to zero as follows

$$
\begin{gathered}
\frac{d(\text { Year })}{d(\text { Cumulative sea level })}=\frac{d\left(-0.0003 x^{2}+0.3751 x+1890.1\right)}{d x}-0.0006 x+0.3751 \\
-0.0006 x+0.3751=0
\end{gathered}
$$

The year corresponding to the stationary point of the model is determined by substituting the sea level, $x=625.167$ inches into the model in Figure 10 as follows.

$$
\begin{gathered}
\text { Year, } y=-0.0003(625.167)^{2}+0.3751(625.167)+1890.1=2017.16 \\
\therefore \text { the year, } y=2016.47
\end{gathered}
$$

Hence, beyond 2017, the model cannot be used to predict sea level rise. in mid-2016 the model yields the maximum year. As the sea continues to rise beyond 625.167, the model yields decreasing years. This model was therefore replaced by a linear model (Figure 11), which was developed by plotting years with respect to the corresponding sea level.

The model (Figure 11) was used to predict years that the sea level would rise to the elevations above sea level of the coastal low land parishes of Southeastern Louisiana. To determine the year that sea level would equal the elevation above sea level for a parish the magnitude of the elevation above sea level is substituted for $\mathrm{x}$ (the independent variable) in the model of year versus the elevation above sea level (Figure 11), presented as follows.

$$
y=0.224 x+1900
$$

The elevations given by the key based on the topographic map showing Louisiana State risks from rising sea level were used as the independent variables [55]. The data was derived from USGS Digital Elevation Data. The parishes at risk of sea level rise were classified as having the levels, $0-5 \mathrm{ft}, 5-10 \mathrm{ft}, 10-15$ $\mathrm{ft}, 15-20 \mathrm{ft}, 20-25 \mathrm{ft}, 25-30 \mathrm{ft}$ and $30-50 \mathrm{ft}$ respectively [55]. The highest elevations above sea level for the classifications are, $5 \mathrm{ft}, 10 \mathrm{ft}, 15 \mathrm{ft}, 20 \mathrm{ft}$ and $25 \mathrm{ft}$,

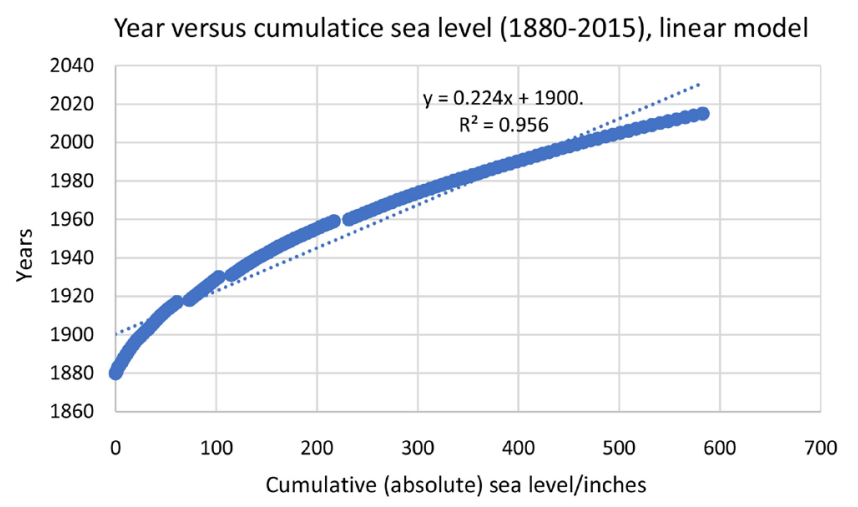

Figure 11. Years versus cumulative sea level (linear model). 
$30 \mathrm{ft}$, and $50 \mathrm{ft}$, respectively. The corresponding absolute elevations above sea level were computed by adding, $524.25 \mathrm{in}$, the absolute sea level with respect to the datum elevation of 1880 to $5 \mathrm{ft}, 10 \mathrm{ft}, 15 \mathrm{ft}, 20 \mathrm{ft}$ and $25 \mathrm{ft}$, respectively. Hence, the absolute elevations above sea level for the classifications are given as, $584.25 \mathrm{in}, 644.25 \mathrm{in}, 704.25 \mathrm{in}, 764.25 \mathrm{in}, 824.25$ in and 884.25 in and $1124.25 \mathrm{ft}$, respectively. The following table (Table 6) illustrates the year when the sea level is expected to have risen and equaled the given elevations above sea level for each of the parishes within the study area.

A plot of sea level rise versus years data suggests that the rate of sea level rise increased as years progress. Hence, the actual sea levels could be greater than the figures presented in table (Table 5). Models representing increased rates of sea level rise with respect to time/years were developed from the data collected between 2006 and 2015 through linear regression using Microsoft Excel tool kit. It is illustrated in Figure 12.

The following equation represents the model.

$$
y=0.1219 x+1944.1
$$

To stress the importance and urgency of mitigation for the risk, Baton Rouge, with an elevation above sea level of 56ft (1196.25 inches above 1880 datum) has also been included in Table 7. This model was used to predict the year that the sea level will rise to equal the elevations above sea level for the parishes being studied.

Table 6. Absolute elevation of coastal low land Louisiana parishes and years that the sea level will equal to the elevations, based on 1880-2015 data modeling.

\begin{tabular}{cc}
\hline Absolute elevation above sea level/inches & Year \\
\hline 584.25 & 2031.23 \\
644.25 & 2044.676 \\
704.25 & 2058.122 \\
764.25 & 2071.568 \\
824.25 & 2085.014 \\
884.25 & 2098.46 \\
1124.25 & 2152.244 \\
\hline
\end{tabular}

Table 7. Illustration of elevation of parishes above sea level and the year expected for the sea level to rise the magnitude, based on the model illustrated in Figure 10.

\begin{tabular}{ccc}
\hline $\begin{array}{c}\text { Absolute elevation above sea level in inches to } \\
\text { parishes elevations above sea level in inches }\end{array}$ & $\begin{array}{c}\text { Predicted year } \\
\text { for the sea to rise }\end{array}$ & $\begin{array}{c}\text { Elevation above } \\
\text { sea level in feet }\end{array}$ \\
\hline 584.25 & 2015.32 & 5 \\
644.25 & 2022.634 & 10 \\
704.25 & 2029.948 & 15 \\
764.25 & 2037.262 & 20 \\
824.25 & 2044.576 & 25 \\
884.25 & 2051.89 & 30 \\
1124.25 & 2081.146 & 50 \\
1196.25 & 2089.923 & 56 \\
\hline
\end{tabular}




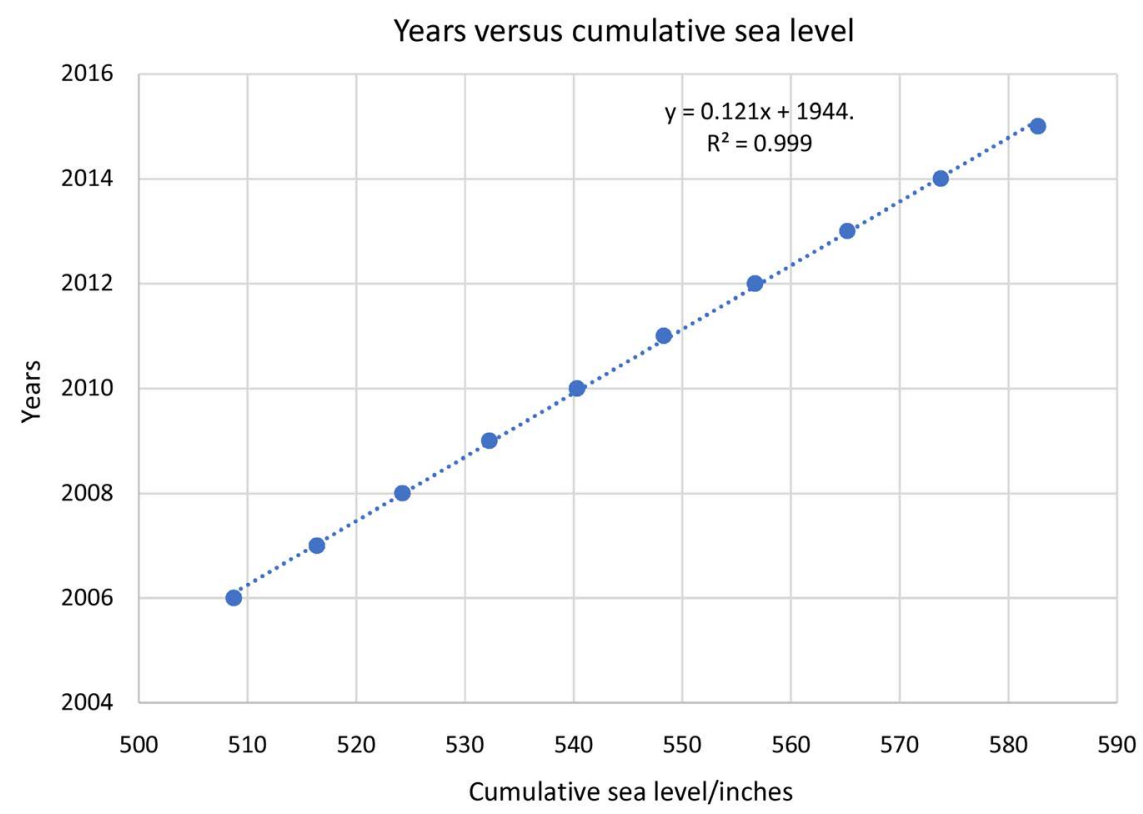

Figure 12. Variation of years with respect to cumulative sea level (based on 2005-2015 data).

The years and corresponding elevations above the sea level are illustrated in Table 7.

The results presented in Table 7 reveal a high sea level rise rate, suggesting that the sea level could equal elevations above the sea level for some parishes sooner than expected. However, the rate of sea level rise is a function of many external factors such as storms, hurricanes, among others, whose pattern is dynamic. Hence, it could decrease to the 1970-2015 rate or even, lower.

\section{Conclusions}

An examination of the population of individual parishes indicates that there was drop in population in some of the coastal low land parishes while there was increase in others (Table 2). This could have been a result of people moving from parishes which they believed were high risk to safer parishes, following floods or hurricanes. An analysis of sea level rise suggests that these safe areas risk experiencing floods and other impacts associated with the rise. The rate of sea level rise is gradually increasing as shown from the analysis of the data. While the expected population in Louisiana's coastal lands will be about 1.8 million, the model presented in Figure 5 suggests that the sea level would have risen to 740 inches, an increase of over 440 inches, just between 1970 and 2040. This prediction is based on the general rate of sea level rise between 1970 and 2015, which is higher than the rate based on the entire data. The linear model based on the entire data (1880-2015) predicted an absolute sea level of 600 in by 2040. This would have been the expected absolute sea level by 2040, in the absence of humans' contribution to accelerated global climate change and interference with surface water flow. 
The rise in sea level may lead to increased risk of total flooding of coastal parishes since these areas will gradually be equal to or lower than the sea level, resulting inability of water to be drained in the event increased surface water flows from storms etc. Water flows from high to low elevations. Any area whose elevation is equal or lower than the sea level is a potential reservoir of water during floods. Once the sea rises above these elevations, sea water can also flood them. As the human population rises in the coastal parish's investments, in the forms of enterprises, schools, and homes etc., in these areas also increase. Flooding of the area could result in loss of human life, investments, and ecosystems, etc. The government should invest heavily in pressure walls (levees) to prevent water from flooding the coastal lowlands to prevent or minimize loss of life, investments, heritage, ecosystems, and injury etc.

\section{Conflicts of Interest}

The authors declare no conflicts of interest regarding the publication of this paper.

\section{References}

[1] McGeehin, M.A. and Mirabelli, M. (2001) The Potential Impacts of Climate Variability and Change on Temperature-Related Morbidity and Mortality in the United States. Environmental Health Perspectives, 109, 185-189. https://doi.org/10.2307/3435008

[2] Anthoff, D., Nicholls, R.J. and Tol, R.S.J. (2010) The Economic Impact of Substantial Sea-Level Rise. Mitigation and Adaptation Strategies for Global Change, 15, 321-335. https://doi.org/10.1007/s11027-010-9220-7

[3] United Nations General Assembly (1992) Report of the United Nations Conference on Environment and Development. Rio de Janeiro, 3-14 June 1992. A/CONF.151/26 (Vol. I).

https://www.un.org/en/development/desa/population/migration/generalassembly/d ocs/globalcompact/A_CONF.151_26_Vol.I_Declaration.pdf

[4] Keating, M. (1993) The Earth Summit's Agenda for Change: A plain Language Version of Agenda 21 and the Other Rio Agreements. Centre for Our Common Future, Geneva, $70 \mathrm{p}$.

[5] The Guardian (2011) What Is the Kyoto Protocol and Has It Made Any Difference? https://www.theguardian.com/environment/2011/mar/11/kyoto-protocol

[6] UNFCCC (2014) Kyoto Protocol. http://unfccc.int/kyoto_protocol/items/2830.php

[7] United Nations Framework Convention on Climate Change (UNFCCC) (2020) What Is the Paris Agreement?

https://unfccc.int/process-and-meetings/the-paris-agreement/what-is-the-paris-agr eement

[8] International Institute for Applied Systems Analysis (IIASA) (2020) Sea Level Rise to Cause Major Economic Impact in the Absence of Further Climate Action. Science Daily. http://www.sciencedaily.com/releases/2020/01/200127134809.htm

[9] Marzeion, B., Cogley, J.G., Richter, K. and Parkes, D. (2014) Attribution of Global Glacier Mass Loss to Anthropogenic and Natural Causes. Science, 345, 919-921. https://doi.org/10.1126/science.1254702 
[10] Olivier, J.G.J., Janssens-Maenhout, G., Muntean, M. and Peters, J.H.A.W. (2016) Trends in Global $\mathrm{CO}_{2}$ Emissions-2014 Report. JRC Report 93171/PBL Netherlands Environmental Assessment Agency, Report 1490.

http://edgar.jrc.ec.europa.eu/news_docs/jrc-2016-trends-in-global-co2-emissions-2 016-report-103425.pdf

[11] Cornwall, W. (2020) Humans Are a Bigger Source of Climate-Altering Methane, New Studies Suggest. Science. https://doi.org/10.1126/science.abb3937

https://www.sciencemag.org/news/2020/02/only-humans-can-create-climate-alterin g-methane-burns-new-studies-suggest

[12] U.S. Environmental Protection Agency (EPA) (2019) Greenhouse Gas Emissions: Global Greenhouse Gas Emissions Data.

https://www.epa.gov/ghgemissions/global-greenhouse-gas-emissions-data

[13] Olivier, J.G.J., Janssens-Maenhout, G., Muntean, M. and Peters, J.H.A.W. (2015) Trends in Global $\mathrm{CO}_{2}$ Emissions-2015 Report. JRC Report 98184/PBL Report 1803.

http://edgar.jrc.ec.europa.eu/news_docs/jrc-2015-trends-in-global-co2-emissions-2 015-report-98184.pdf

[14] Olivier, J.G.J., Janssens-Maenhout, G., Muntean, M. and Peters, J.H.A.W. (2016) Trends in Global $\mathrm{CO}_{2}$ Emissions-2016 Report. JRC Report 93171/PBL Netherlands Environmental Assessment Agency, Report 1490.

http://edgar.jrc.ec.europa.eu/news_docs/jrc-2016-trends-in-global-co2-emissions-2 016-report-103425.pdf

[15] Borroto, R.J. (1997) Global Warming, Rising Sea Level, and Growing Risk of Cholera Incidence: A Review of Literature and Evidence. GeoJournal, 44, 111-120. https://doi.org/10.1023/A:1006821725244

[16] U.S. Environmental Protection Agency (EPA) (2020) Greenhouse Gas Emissions: Sources of Greenhouse Gas Emissions April 11, 2020.

https://www.epa.gov/ghgemissions/sources-greenhouse-gas-emissions

[17] Boon, J.D. (2012) Evidence of Sea Level Acceleration at U.S. and Canadian Tide Stations, Atlantic Coast, North America. Journal of Coastal Research, 28, 1437-1445. https://doi.org/10.2112/JCOASTRES-D-12-00102.1

[18] Khan, S.A., Kjaer, K.H., Bevis, M., Bamber, J.L., Wahr, J., Kjeldsen, K.K., Bjork, A.A., Korsgaard, N.J., Stearns, L.A., van den Broeke, M.R., Liu, L., Larsen, N.K. and Muresan, I.S. (2014) Sustained Mass Loss of the Northeast Greenland Ice Sheet Triggered by Regional Warming. Nature Climate Change, 4, 292-299. https://doi.org/10.1038/nclimate2161

[19] Moftakhari, H.R., AghaKouchak, A., Sanders, B.F., Feldman, D.L., Sweet, W., Matthew, R.A. and Luke, A. (2015) Increased Nuisance Flooding along the Coasts of the United States Due to Sea Level Rise: Past and Future. Geophysical Research Letters, 42, 9846-9852. https://doi.org/10.1002/2015GL066072

[20] Sweet, W.V., Kopp, R.E., Weaver, C.P., Obeysekera, T., Horton, R.M., Thieler, E.R. and Zervas, C. (2017) Global and Regional Sea Level Rise Scenarios for the United States. NOAA Technical Report NOS CO-OPS 083. National Oceanic and Atmospheric Administration, National Ocean Service, Silver Spring, 75 p. https://tidesandcurrents.noaa.gov/publications/techrpt83_Global_and_Regional_SL R_Scenarios_for_the_US_final.pdf

[21] Pulver, D.V. (2017) Sea Level Rise Is Accelerating in Florida, Scientists Warn. Washington Times, Thursday, July 20, 2017.

https://www.washingtontimes.com/news/2017/jul/20/sea-level-rise-is-accelerating-i 
n-florida-scientis

[22] Vousdoukas, M.I., Mentaschi, L., Voukouvalas, E., Verlaan, M. and Feyen, L. (2017) Extreme Sea Levels on the Rise along Europe's Coasts. Earth's Future, 5, 304-323. https://doi.org/10.1002/2016EF000505

[23] Boesch, D.F., Boicourt, W.C., Cullather, R.I., Ezer, T., Galloway, G.E., Johnson, Z.P., Kilbourne, K.H., Kirwan, M.L., Kopp, R.E., Land, S., Li, M., Nardin, W., Sommerfield, C.K. and Sweet, W.V. (2018) Sea-Level Rise: Projections for Maryland 2018. University of Maryland Center for Environmental Science, Cambridge, $27 \mathrm{p}$. https://www.umces.edu/sites/default/files/Sea-Level\%20Rise\%20Projections\%20for \%20Maryland\%202018_1.pdf

[24] Domingues, R., Goni, G., Baringer, M. and Volkov, D. (2018) What Caused the Accelerated Sea Level Changes along the U.S. East Coast during 2010-2015? Geophysical Research Letters, 45, 13,367-13,376. https://doi.org/10.1029/2018GL081183

[25] European Environment Agency (EEA) (2019) Global and European Sea-Level Rise. https://www.eea.europa.eu/data-and-maps/indicators/sea-level-rise-6/assessment

[26] Lindsey, R. (2019) Climate Change: Global Sea Level. National Oceanic and Atmospheric Administration (NOAA), National Ocean Service, Silver Spring. https://www.climate.gov/news-features/understanding-climate/climate-change-glob $\underline{\text { al-sea-level }}$

[27] Hausfather, Z. (2019) Explainer: How Climate Change Is Accelerating Sea Level Rise.

https://www.carbonbrief.org/explainer-how-climate-change-is-accelerating-sea-leve $\underline{\text { l-rise }}$

[28] Mufson, S. (2020) Boston Harbor Brings Ashore a New Enemy: Rising Seas. The Washington Post February 20, 2020.

https://www.boston.com/news/local-news/2020/02/20/boston-harbor-brings-ashore -a-new-enemy-rising-seas

[29] Milman, O. (2020) Greenland's Melting Ice Raised Global Sea Level by $2.2 \mathrm{~mm}$ in Two Months. The Guardian.

https://www.theguardian.com/science/2020/mar/19/greenland-ice-melt-sea-level-ris e-climate-crisis

[30] Carrington, D. (2020) Losses of Ice from Greenland and Antarctica Are Tracking the Worst-Case Climate Scenario, Scientists Warn. The Guardian, 11 March 2020.

https://www.theguardian.com/environment/2020/mar/11/polar-ice-caps-melting-si x-times-faster-than-in-1990s

[31] National Research Council (2012) Sea-Level Rise for the Coasts of California, Oregon, and Washington: Past, Present, and Future. The National Academies Press, Washington DC. https://doi.org/10.17226/13389

[32] Vousdoukas, M.I., Mentaschi, L., Voukouvalas, E., Verlaan, M. and Feyen, L. (2017) Extreme Sea Levels on the Rise along Europe's Coasts. Earth's Future, 5, 304-323. https://doi.org/10.1002/2016EF000505

[33] IPCC (2019) IPCC Special Report on the Ocean and Cryosphere in a Changing Climate.

https://www.ipcc.ch/site/assets/uploads/sites/3/2019/12/SROCC_FullReport_FINAL .pdf

[34] Wikipedia (2020) Sea Level Rise. https://en.wikipedia.org/wiki/Sea_level_rise

[35] Slangen, A.B.A., Carson, M., Katsman, C.A., van de Wal, R.S.W., Köhl, A., Vermeersen, L.L.A. and Stammer, D. (2014) Projecting Twenty-First Century Regional Sea-Level Changes. Climate Change, 124, 317-332. 
https://doi.org/10.1007/s10584-014-1080-9

[36] U.S. Environmental Protection Agency (EPA) (2017) Climate Impacts on Coastal Areas. EPA.

https://archive.epa.gov/epa/climate-impacts/climate-impacts-coastal-areas.html

[37] LaBelle, R.M., Zaim-Sassi, N., Qin, H. and Xie, H. (2019) Rising Sea Levels: How Rising Sea Levels Are Threatening Coastal Cities and Those Most Vulnerable. Storymaps. https://storymaps.arcgis.com/stories/0037ed91445841629cb387d652b079ea

[38] Climate Central (2019) Report: Flooded Future: Global Vulnerability to Sea Level Rise Worse than Previously Understood. Climate Central, October 29th, 2019. https://www.climatecentral.org/news/report-flooded-future-global-vulnerability-tosea-level-rise-worse-than-previously-understood

[39] Nordhaus, W.D. and Boyer, J.G. (2003) Warming the World: Economic Models of Global Warming. MIT Press, Cambridge, $244 \mathrm{p}$.

[40] Withey, P., Lantz, V.A. and Ochuodho, T.O. (2015) Economic Costs and Impacts of Climate-InducedSea-Level Rise and Storm Surge in Canadian Coastal Provinces: A CGE Approach. Applied Economics, 48, 59-71. https://doi.org/10.1080/00036846.2015.1073843

[41] Warren-Myers, G., Aschwanden, G., Fuerst, F. and Krause, A. (2018) Estimating the Potential Risks of Sea Level Rise forPublic and Private Property Ownership, Occupationand Management. Risks, 6, 37. https://doi.org/10.3390/risks6020037

[42] The Associated Press (2019) Tropical Storm Barry Brings Heavy Rains, Floods to Louisiana. CBC News.

https://www.cbc.ca/news/world/louisiana-barry-saturday-1.5210966

[43] Steward, S. (2014) 2012 Atlantic Hurricane Season. National Hurricane Center Annual Summary. https://www.nhc.noaa.gov/data/tcr/summary_atlc_2012.pdf

[44] Amadeo, K. (2020) Hurricane Katrina Facts, Damage, and Costs: What Made Katrina So Devastating. The Balance, February 27, 2020.

https://www.thebalance.com/hurricane-katrina-facts-damage-and-economic-effects $\underline{-3306023}$

[45] CNN Library (2019) Hurricane Katrina Statistics Fast Facts. https://www.cnn.com/2013/08/23/us/hurricane-katrina-statistics-fast-facts/index.ht $\underline{\mathrm{ml}}$

[46] Merem, E.C., Twumasi, Y.A., Foster, D., Richardson, C. and Yeramilli, S. (2012) Using GIS and Climate Risks Information to Analyze the Vulnerability of Coastal Counties in Louisiana and Mississippi. Resources and Environment, 2, 1-16. https://doi.org/10.5923/j.re.20120201.01

[47] U.S. Department of Commerce, National Oceanic and Atmospheric Administration (NOAA) (2019) Tropical Cyclone Annual Summaries 1872-2006 (Monthly Weather Review). https://www.nhc.noaa.gov/data/\#monthly

[48] Environmental Defense Fund (EDF) (2010) Hurricanes and Climate Change. Loui-siana's Coast: What's at Stake. New York, 1-2.

[49] U.S. Department of Commerce, National Oceanic and Atmospheric Administration (NOAA) (2007) Monthly Weather Review-Annual Summaries of North Atlantic Storms, 1872-2011. NOAA Miami Regional Library. https://www.aoml.noaa.gov/general/lib/lib1/nhclib/mwreviews.html

[50] U.S. Department of Commerce, National Oceanic and Atmospheric Administration (NOAA) (2020) National Hurricane Center (NHC) and Central Pacific Hurricane Center Data Archive. https://www.nhc.noaa.gov/data 
[51] Climate Central (2020) An Interactive Map of Land Projected to Be below Tideline in 2050 .

https://coastal.climatecentral.org/map/7/-91.2009/31.6376/?theme=sea_level_rise\& map_type=coastal_dem_comparison\&elevation_model=coastal_dem\&forecast_year $=2050 \&$ pathway $=$ rcp $45 \&$ percentile $=$ p50\&return_level=return_level_0\&slr_model= kopp_2014

[52] U.S. Census (2010) Louisiana: 2010 Population and Housing Unit Counts. https://www.census.gov/prod/cen2010/cph-2-20.pdf

[53] World Population Review (2019) Population of Counties in Louisiana (2020). http://worldpopulationreview.com/us-counties/la

[54] Data Distributed by Atlas (2020) The Louisiana Statewide GIS. LSU Department of Geography and Anthropology, Baton Rouge. http://atlas.lsu.edu

[55] Kosovich, J.J. (2008) State of Louisiana-Highlighting Low-Lying Areas Derived from USGS Digital Elevation Data. Scientific Investigations Map 3049 Version 1.0. US Geological Survey. https://pubs.usgs.gov/sim/3049/downloads/SIM3049.pdf https://doi.org/10.3133/sim3049

[56] U.S. Environmental Protection Agency (EPA) (2016) Global Average Absolute Sea Level Change, 1880-2015.EPA's Climate Change Indicators in the United States. Office of Atmospheric Programs (MC-6207A), Washington DC. https://www.epa.gov/sites/production/files/2016-08/sea-level_fig-1.csv

[57] Youssef, A. (2020) Logic and Proof: A Brief Summary. https://www2.seas.gwu.edu/ ayoussef/cs1311/Logic.pdf 